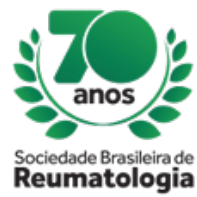

\title{
BAGGIO-YOSHINARI SYNDROME - A CASE SERIES
}

SAMARA LIBICH GUSMÃO GIGANTE (HOSPITAL DAS CLÍNICAS - USP RIBEIRÃO, RIBEIRÃO PRETO, SP, Brasil), LETÍCIA PASTORELLI BONJORNO (HOSPITAL DAS CLÍNICAS - USP RIBEIRÃO, RIBEIRÃO PRETO, SP, Brasil), SAULO MUSSE DIB (HOSPITAL DAS CLÍNICAS - USP RIBEIRÃO, RIBEIRÃO PRETO, SP, Brasil), PÂMELLA INDIRA SILVA OLIVEIRA MENEZES (HOSPITAL DAS CLÍNICAS - USP RIBEIRÃO, RIBEIRÃO PRETO, SP, Brasil), MARIA EUGÊNIA FARIAS TEIXEIRA (HOSPITAL DAS CLÍNICAS - USP RIBEIRÃO, RIBEIRÃO PRETO, SP, Brasil), PAULO LOUZADA-JR (HOSPITAL DAS CLÍNICAS - USP RIBEIRÃO, RIBEIRÃO PRETO, SP, Brasil), RENE DONIZETI RIBEIRO OLIVEIRA (HOSPITAL DAS CLÍNICAS - USP RIBEIRÃO, RIBEIRÃO PRETO, SP, Brasil)

\section{BACKGROUND}

Brazilian Lyme-simile disease or Baggio-Yoshinari syndrome is an infectious disease difficult to diagnose due to the variable clinical presentation and inability of in vitro isolation of Borrelia burgdorferi sensu stricto transmitted by tick bites. In addition to migratory erythema (ME), in the acute stage, there are frequent constitutional, musculoskeletal and neurological complications. The latent and late stages are difficult to diagnose due to the unusual report of contact with tick, and have neurological, cardiac and joint manifestations. Diagnostic criteria include concomitant ELISA serology and Western blotting (WB). The treatment is performed with antibiotics. Late diagnosis may lead to disability and limited response to antibiotic therapy.

\section{MATERIALS AND METHODS}

Review of medical records with ICD registry A69.2 - Lyme disease. Information collected included: gender, clinical presentation, stage of the disease, serological method, final diagnosis and evolution.

\section{RESULTS}

Men accounted for $60.7 \%$ of the cases, with a mean age of $30.7 \pm 14.1$ years. Thick contact was reported in $21.4 \%$. Among the acute phase diagnoses ( $n=15,53.5 \%$ ), with mean symptom time of $1.5 \pm 1$ month, non-ME skin lesions occurred in $33.3 \%$ of the patients, isolated neurological syndromes in $20 \%$, constitutional symptoms and neurological syndromes in $46.7 \%$ and $33.3 \%$ had only constitutional symptoms. In patients with chronic presentation $(n=13 ; 46.5 \%)$, with an average disease time at diagnosis of $75 \pm 53$ months, neurological syndrome was present in all cases, constitutional symptoms in $53.8 \%$, skin lesions and arthropathy in $7.7 \%$. WB was positive in $42.8 \%$ of cases, ELISA in $7.1 \%$ and both in $28.5 \%$, with negativity of both in $21.5 \%$. Specific antibiotic therapy was instituted in $82.1 \%$ of cases, antibiotic therapy extended to other agents in $12.2 \%$ and no treatment in $3.6 \%$. Complete remission of constitutional symptoms occurred in all patients. Total or partial remission of neurological symptoms was achieved in all of them in the acute phase, while in the chronic phase this occurred in $76.9 \%$.

\section{CONCLUSION}

In this series of cases, the low rate of tick bites reports, the absence of cutaneous lesions typical of the acute phase, and the diagnosis of neurological syndrome in $100 \%$ of chronic Baggio-Yoshinari Syndrome cases are highlighted. In addition, the diagnosis was based on the positivity of only one serological test in most cases. 